\title{
Development of a New Class of Thiocyanate-Free Cyclometalated Ruthenium(II) Complex for Sensitizing Nanocrystalline $\mathrm{TiO}_{2}$ Solar Cells
}

\author{
Surya Prakash Singh, Ashraful Islam, Masatoshi Yanagida, and Liyuan Han
}

Photovoltaic Materials Unit, National Institute for Materials Science (NIMS), 1-2-1 Sengen, Tsukuba, Ibaraki 305-0047, Japan

Correspondence should be addressed to Liyuan Han, han.liyuan@nims.go.jp

Received 26 January 2011; Accepted 23 February 2011

Academic Editor: Mohamed Sabry Abdel-Mottaleb

Copyright ( $) 2011$ Surya Prakash Singh et al. This is an open access article distributed under the Creative Commons Attribution License, which permits unrestricted use, distribution, and reproduction in any medium, provided the original work is properly cited.

We designed and developed a new class of thiocyanate-free cyclometalated ruthenium sensitizers for sensitizing nanocrystalline $\mathrm{TiO}_{2}$ solar cells. This complex shows appreciably broad absorption range. Anchoring to nanocrystalline $\mathrm{TiO}_{2}$ films for light to electrical energy conversion in regenerative photoelectrochemical cells achieves efficient sensitization to $\mathrm{TiO}_{2}$ electrode. With this new sensitizer, there were a power conversion efficiency of $4.76 \%$, a short-circuit photocurrent density of $11.21 \mathrm{~mA} / \mathrm{cm}^{2}$, an opencircuit voltage of $0.62 \mathrm{~V}$, and a fill factor of 0.68 obtained under standard AM 1.5 sunlight.

\section{Introduction}

A molecular system that consists of a wideband gap semiconductor photoanode, typically $\mathrm{TiO}_{2}$, an anchored molecular photosensitizer, a redox electrolyte, and a platinized photocathode is called dye-sensitized solar cells (DSCs) [1-5]. Among these elements, the sensitizers play a vital role in DSC. A lot of Ru-complex sensitizers [6-16] and organic sensitizers have been developed in DSC [17]. So far, sensitizers such as black dye, N719, and N3 are known as best sensitizers in DSC. Black dye sensitized nanocrystalline $\mathrm{TiO}_{2}$ solar cells yielding solar to electric power conversion efficiency of over $11 \%$ under standard AM 1.5 conditions $[12,13]$. Much effort has been made to increase photovoltaic performance (stability) of a device, towards the development of sensitizers, electrode, and photoanode material. A way to improve the stability is the development of a dye without thiocyanate $(\mathrm{SCN})$ donor ligands because monodentate SCN is believed to provide the weakest dative bonding within the metal complexes, making the sensitizer unstable. Few efforts have been made to replace the SCN donor ligands with effective pyridyl pyrazolate chelating chromophores [18] and 2,4-difluorophenyl pyridinato ancillary ligands [19]. More recently, cycloruthenated compounds have been used as sensitizers for efficient DSC devices [19-24]. Although the preliminary attempts gave only limited success [2024], a superior power conversion efficiency is now achieved with a novel thiocyanate-free cyclometalated sensitizer [19]. However, further development of new sensitizer is still a challenging issue for DSC to improve the efficiency. Here, we report on the new class of thiocyanate-free cyclometalated ruthenium(II) complex for sensitizing nanocrystalline $\mathrm{TiO}_{2}$ solar cells.

\section{Experimental}

2.1. Materials. All the solvents and chemicals were of reagent grade and used as received unless otherwise noted. Chromatographic purification was performed by gel permeation on Sephadex LH-20 (from Sigma).

Synthesis of Complex HIS1. cis-Dichlorobis (4,4'-dicarboxy-2,2'-bipyridine)ruthenium (180 $\mathrm{mg}, 0.27 \mathrm{mmol})$ and 5-phenyl-3-(trifluoromethyl)-1H-pyrazole (117 mg, 0.55 $\mathrm{mmol}$ ) were dissolved in ethylene glycol $(30 \mathrm{~mL})$, and the reaction mixture was heated to $170^{\circ} \mathrm{C}$ under argon for $2 \mathrm{~h}$. Then tetrabutyl ammonium hydroxide $(1.1 \mathrm{~g}, 1.37 \mathrm{mmol})$ was added to the reaction mixture and further heated to $170^{\circ} \mathrm{C}$ under argon for $2 \mathrm{~h}$. After evaporating the solvent, 

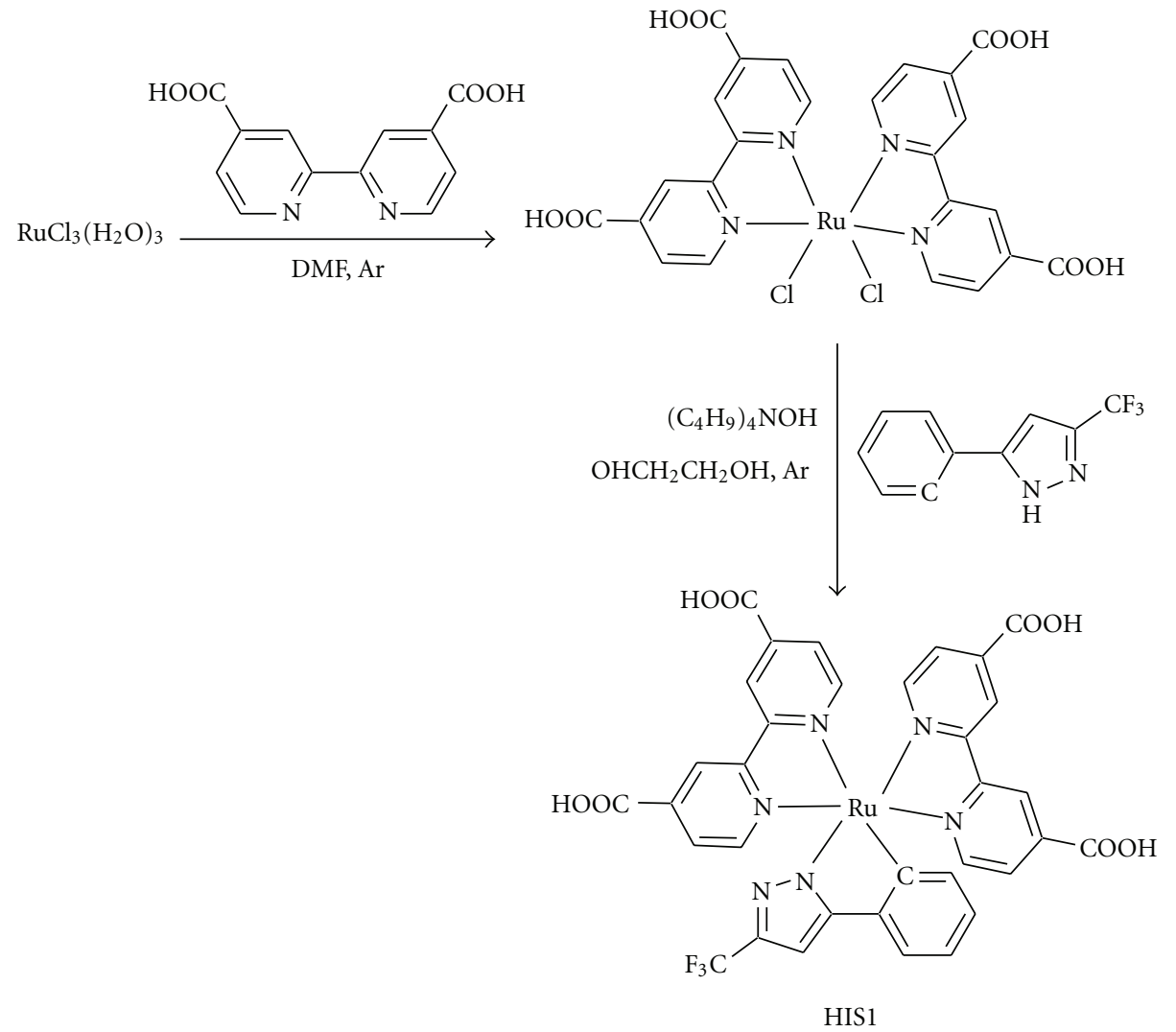

Scheme 1: Synthetic route for Bis (4,4'-dicarboxy-2,2'-bipyridine) 5-phenyl-3-(trifluoromethyl)-1H-pyrazole Ruthenium (II).

the resulting solid was dissolved in water $(15 \mathrm{~mL})$ and was titrated with $0.2 \mathrm{M} \mathrm{HNO}_{3}$ to $\mathrm{pH}$ 3.8. The reaction mixture was kept in a refrigerator overnight and allowed to warm to $25^{\circ} \mathrm{C}$. The resulting precipitation was collected on a sintered glass crucible by suction filtration. The solid was dissolved in a basic water solution ( $\mathrm{pH}$ 10-11) and purified on a Sephadex LH-20 column by eluting with water. The yield, $167 \mathrm{mg} .{ }^{1} \mathrm{H}$ NMR $\left(\mathrm{CD}_{3} \mathrm{OD}\right.$ with a drop of $\left.\mathrm{NaOD}\right): \delta$ 9.04-8.86 (m, 5H), $8.06(\mathrm{~d}, 1 \mathrm{H}), 7.9(\mathrm{~d}, 1 \mathrm{H}), 7.89(\mathrm{~d}, 1 \mathrm{H})$, $7.8(\mathrm{~d}, 1 \mathrm{H}), 7.67(\mathrm{~d}, 2 \mathrm{H}), 7.55(\mathrm{~d}, 2 \mathrm{H}), 7.27(\mathrm{t}, 2 \mathrm{H}), 7.13(\mathrm{t}$, $1 \mathrm{H})$, and $6.92(\mathrm{~s}, 1 \mathrm{H})$.

2.2. Fabrication of Dye-Sensitized Solar Cell. A nanocrystalline $\mathrm{TiO}_{2}$ photoelectrode of $20 \mu \mathrm{m}$ thickness (area: $0.25 \mathrm{~cm}^{2}$ ) was prepared by screen printing on conducting glass as previously described [25]. The films were further treated with $0.05 \mathrm{M} \mathrm{TiCl}_{4}$ and $0.1 \mathrm{M} \mathrm{HCl}$ aqueous solutions before examination [26]. Coating of the $\mathrm{TiO}_{2}$ film was carried out by immersing for $45 \mathrm{~h}$ in a sensitizer solution of $3 \times 10^{-4} \mathrm{M}$ acetonitrile/tert-butyl alcohol $(1 / 1, v / v)$ solution. Deoxycholic acid $(20 \mathrm{mM})$ was added to the dye solution as a coadsorbent to prevent aggregation of the dye molecules [27, 28]. Photovoltaic measurements were performed in a twoelectrode sandwich cell configuration. The dye-deposited $\mathrm{TiO}_{2}$ film and a platinum-coated conducting glass were used as the working electrode and the counterelectrode, respectively. The two electrodes were separated by a surlyn spacer
( $40 \mu \mathrm{m}$ thick) and sealed by heating the polymer frame. The electrolyte was composed of $0.6 \mathrm{M}$ dimethylpropylimidazolium iodide (DMPII), $0.05 \mathrm{M} \mathrm{I}_{2}, \mathrm{TBP} 0.3 \mathrm{M}$, and $0.1 \mathrm{M}$ LiI in acetonitrile.

\section{Results and Discussion}

Scheme 1 shows the synthetic approach for the synthesis of thiocyanate-free cyclometalated ruthenium (II) complex HIS1.

The absorption spectrum of the complex HIS1 is dominated by metal to ligand charge transfer transitions (MLCTs) and shows MLCT bands in the visible region at $546 \mathrm{~nm}$ with a molar extinction coefficient of $12 \times 10^{3} \mathrm{M}^{-1} \mathrm{~cm}^{-1}$. There are high-energy bands at $380 \mathrm{~nm}$ due to ligand $\pi-\pi^{*}$ charge transitions. A comparison of UV-vis spectra of the HIS1 and N719 complexes is displayed in Figure 1.

To get an insight into the electron distribution of this new series of complexes for better understanding of the charge injection and dye regeneration process, the highest occupied molecular orbital (HOMO) and the lowest unoccupied molecular orbital (LUMO) of complex HIS1 were calculated using Gaussian-09 program package (Figure 2). The HOMO of cyclometalated complexes of type $\left[\operatorname{Ru}\left(N^{\wedge} N^{\wedge} N\right)\right.$ $\left.\operatorname{Ru}\left(N^{\wedge} N^{\wedge} C\right)\right]$ and $\left[\operatorname{Ru}\left(N^{\wedge} N\right)_{2}\left(C^{\wedge} N\right)^{+}\right]$is typically extended over the metal and, to a lesser extent, the anionic portion of the cyclometalating ligand [29]. The LUMO typically resides 


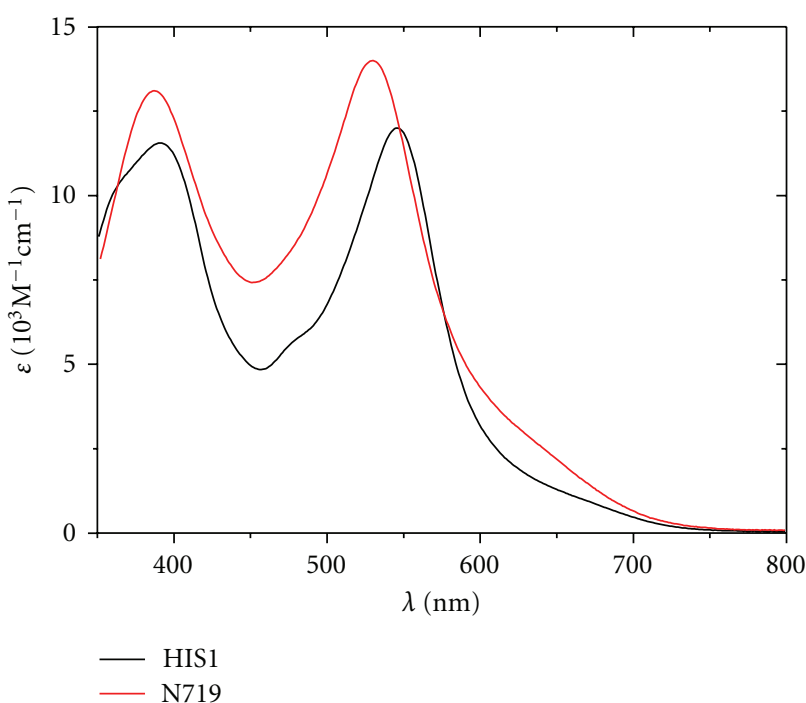

FIgURE 1: UV-vis absorption spectra of complex HIS1 (black line) and N719 (red line), measured in ethanol solution.

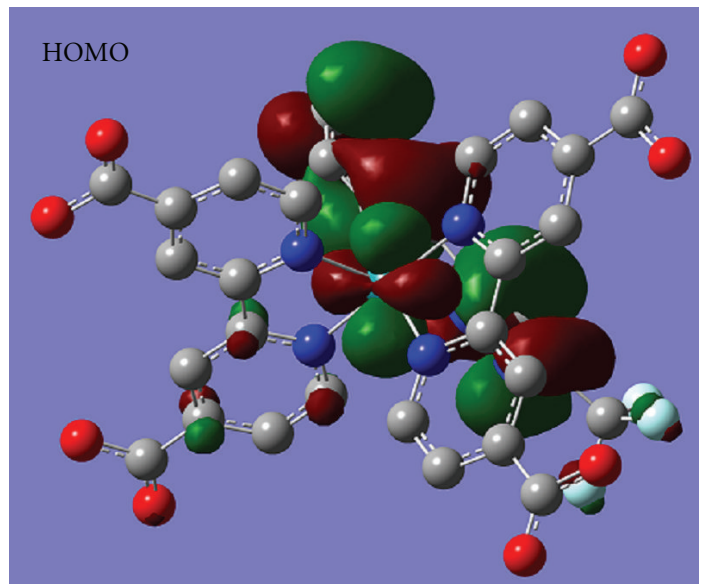

(a)

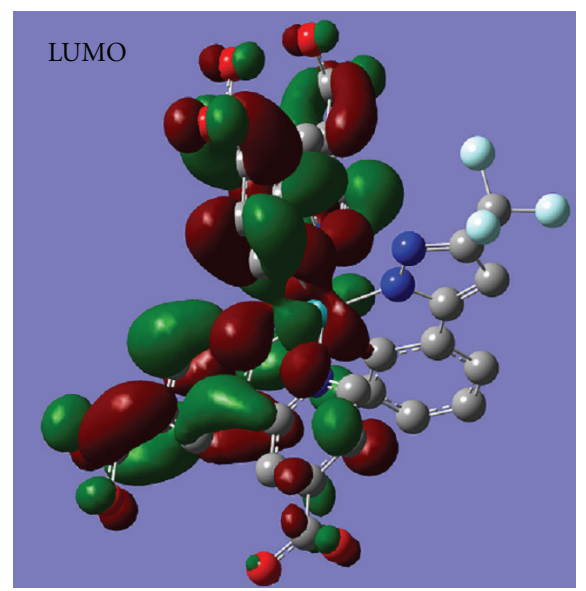

(b)

FIGURE 2: Graphic representation of frontier molecular orbital of complex HIS1.

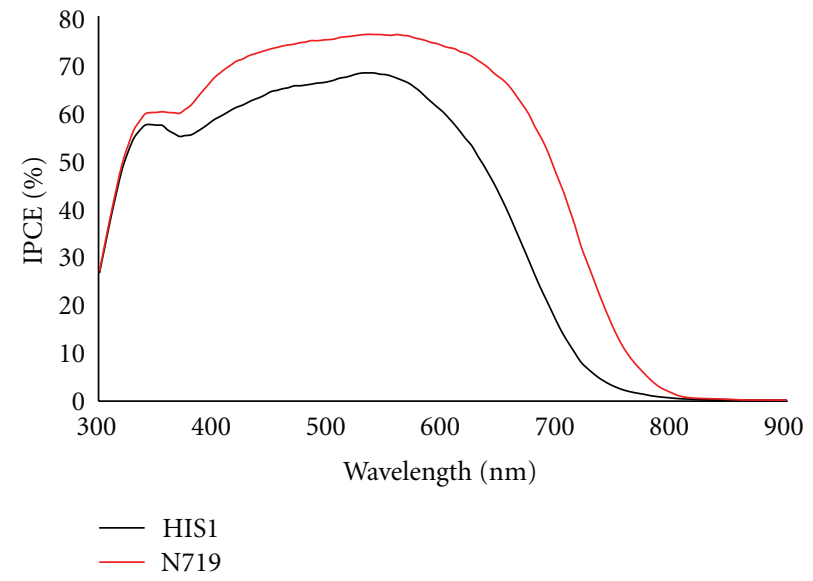

FIGURE 3: Incident photon-to-current conversion efficiency (IPCE) spectra of complex HIS1 (black line) and N719 (red line).

on the neutral polypyridyl ligands along with low-lying excited states delocalized over the polypyridyl portion(s) cyclometalating ligand (Figure 2).

Ionization potential of complex HIS1 bound to nanocrystalline $\mathrm{TiO}_{2}$ film was determined using a photoemission yield spectrometer (Riken Keiki, AC-3E). The ground-state oxidation potentials $\left(\mathrm{Ru}^{3+/ 2+}\right)$ value of $-5.95 \mathrm{eV}$ obtained for sensitizer HIS1 was low enough for efficient regeneration of the oxidized dye through reaction with iodide. The excitedstate oxidation potential, $E^{*}\left(\mathrm{Ru}^{3+/ 2+}\right)$, of sensitizer HIS1 was estimated to be $-4.18 \mathrm{eV}$.

Monochromatic incident photon-to-current conversion efficiency (IPCE) for the solar cell, plotted as a function of excitation wavelength, was recorded on a CEP-2000 system (Bunkoh-Keiki Co. Ltd.). IPCE at each incident wavelength was calculated from (1), where $I_{\mathrm{sc}}$ is the photocurrent density at short circuit in $\mathrm{mA} \mathrm{cm}{ }^{-2}$ under monochromatic irradiation, $q$ is the elementary charge, $\lambda$ is the wavelength of incident radiation in $\mathrm{nm}$, and $P_{0}$ is the incident radiative flux in $\mathrm{Wm}^{-2}$,

$$
\operatorname{IPCE}(\lambda)=1240\left(\frac{I_{\mathrm{SC}}}{q \lambda P_{0}}\right)
$$

The photocurrent density-voltage curves and incident photon-to-current efficiency (IPCE) spectra of the cells based on sensitizer HIS1 under the illumination of air mass (AM) 1.5 sunlight $\left(100 \mathrm{~mW} / \mathrm{cm}^{2}\right.$, WXS-155S-10: Wacom Denso Co., Japan). Figure 3 shows the action spectra of monochromatic incident photon-to-current conversion efficiency (IPCE) for DSC composed of complex HIS1 sensitized nanocrystalline $\mathrm{TiO}_{2}$ electrode and an iodine/triiodide redox electrolyte with reference to N719-based DSC constructed under comparable conditions. Although complex HIS1 shows somewhat lower IPCE values, this problem could be solved using structural modification of complex HIS1, a subject for future research. We observed an IPCE of $68 \%$ in complex HIS1, while in the case of N719, the IPCE was $76 \%$. The dye-sensitized solar cell based on sensitizer 
HIS1 achieves a conversion efficiency $(\eta)$ of $4.76 \%$, a shortcircuit photocurrent density of $11.21 \mathrm{~mA} / \mathrm{cm}^{2}$, an opencircuit voltage of $0.62 \mathrm{~V}$, and a fill factor of 0.68 obtained under standard AM 1.5 sunlight. N719-sensitized solar cell under the same cell fabrication and efficiency measuring procedures achieves a conversion efficiency $(\eta)$ of $7.56 \%$, a short-circuit photocurrent density of $15.83 \mathrm{~mA} / \mathrm{cm}^{2}$, an open-circuit voltage of $0.65 \mathrm{~V}$, and a fill factor of 0.73 . The photo-induced voltage ( $V o c$ ) is determined by the difference between the quasi-Fermi level of $\mathrm{TiO}_{2}$ and redox potential of the electrolyte and is able to be enhanced as a slow recombination process of injected electrons in $\mathrm{TiO}_{2}$ with oxidized species and a negative shift of band edge. tert-butylpyridine (TBP) is known to increase $V$ oc of DSC due to an enhanced electron lifetime and a negative shift of band edge $[30,31]$. Hence, the higher $V$ oc with electrolyte containing $0.3 \mathrm{M}$ TBP is $(0.62 \mathrm{~V})$ and without TBP $0.50 \mathrm{~V}$ observed.

\section{Conclusions}

In summary, a new class of thiocyanate-free cyclometalated ruthenium-based dye HIS1 was strategically designed and synthesized. This complex shows appreciably broad absorption range. Anchoring to nanocrystalline $\mathrm{TiO}_{2}$ films for light to electrical energy conversion in regenerative photoelectrochemical cells achieves efficient sensitization to $\mathrm{TiO}_{2}$ electrode. With this new sensitizer power, there were a conversion efficiency of $4.76 \%$, a short-circuit photocurrent density of $11.21 \mathrm{~mA} / \mathrm{cm}^{2}$, an open-circuit voltage of $0.62 \mathrm{~V}$, and a fill factor of 0.68 obtained under standard AM 1.5 sunlight. Further improvement in the solar cell efficiency as well as the dynamic study of electron injection and recombination in complex HIS1 sensitized nanostructured $\mathrm{TiO}_{2}$ is currently on progress in our lab and will be disclosed in due course.

\section{References}

[1] B. O’Regan and M. Grätzel, "A low-cost, high-efficiency solar cell based on dye-sensitized colloidal $\mathrm{TiO}_{2}$ films," Nature, vol. 353, no. 6346, pp. 737-740, 1991.

[2] A. Hagfeld and M. Grätzel, "Light-induced redox reactions in nanocrystalline systems," Chemical Reviews, vol. 95, no. 1, pp. 49-68, 1995.

[3] A. Hagfeldt and M. Grätzel, "Molecular photovoltaics," Accounts of Chemical Research, vol. 33, no. 5, pp. 269-277, 2000.

[4] M. Grätzel, "Solar energy conversion by dye-sensitized photovoltaic cells," Inorganic Chemistry, vol. 44, no. 20, pp. 68416851, 2005.

[5] M. Grätzel, "Conversion of sunlight to electric power by nanocrystalline dye-sensitized solar cells," Journal of Photochemistry and Photobiology A, vol. 164, no. 1-3, pp. 3-14, 2004.

[6] A. Islam, H. Sugihara, and H. Arakawa, "Molecular design of ruthenium(II) polypyridyl photosensitizers for efficient nanocrystalline $\mathrm{TiO}_{2}$ solar cells," Journal of Photochemistry and Photobiology A, vol. 158, no. 2-3, pp. 131-138, 2003.

[7] A. Hagfeldt, G. Boschloo, L. Sun, L. Kloo, and H. Pettersson, "Dye-sensitized solar cells," Chemical Reviews, vol. 110, no. 11, pp. 6595-6663, 2010.
[8] T. Funaki, M. Yanagida, N. Onozawa-Komatsuzaki, K. Kasuga, Y. Kawanishi, and H. Sugihara, "Efficient panchromatic sensitization of nanocrystalline $\mathrm{TiO}_{2}$-based solar cells using 2-pyridinecarboxylate-substituted Ruthenium(II) complexes," Chemistry Letters, vol. 38, no. 1, pp. 62-63, 2009.

[9] A. Islam, F. A. Chowdhury, Y. Chiba et al., "Synthesis and characterization of new efficient tricarboxyterpyridyl ( $\beta$-diketonato) ruthenium(II) sensitizers and their applications in dye-sensitized solar cells," Chemistry of Materials, vol. 18, no. 22, pp. 5178-5185, 2006.

[10] M. K. Nazeeruddin, P. Péchy, T. Renouard et al., "Engineering of efficient panchromatic sensitizers for nanocrystalline $\mathrm{TiO}_{2}$ based solar cells," Journal of the American Chemical Society, vol. 123, no. 8, pp. 1613-1624, 2001.

[11] A. Islam, F. A. Chowdhury, Y. Chiba et al., "Ruthenium(II) tricarboxyterpyridyl complex with a fluorine-substituted $\beta$ diketonato ligand for highly efficient dye-sensitized solar cells," Chemistry Letters, vol. 34, no. 3, pp. 344-345, 2005.

[12] Y. Chiba, A. Islam, Y. Watanabe, R. Komiya, N. Koide, and L. Han, "Dye-sensitized solar cells with conversion efficiency of 11.1\%," Japanese Journal of Applied Physics, vol. 45, no. 25, pp. L638-L640, 2006.

[13] Q. Wang, S. Ito, M. Grätzel et al., "Characteristics of high efficiency dye-sensitized solar cells," Journal of Physical Chemistry B, vol. 110, no. 50, pp. 25210-25221, 2006.

[14] A. Islam, H. Sugihara, M. Yanagida et al., "Efficient panchromatic sensitization of nanocrystalline $\mathrm{TiO}_{2}$ films by $\beta$ diketonato ruthenium polypyridyl complexes," New Journal of Chemistry, vol. 26, no. 8, pp. 966-968, 2002.

[15] S. Gao, A. Islam, Y. Numata, and L. Han, "A $\beta$-diketonato ruthenium(II) complex with high molar extinction coefficient for panchromatic sensitization of nanocrystalline $\mathrm{TiO}_{2}$ film," Applied Physics Express, vol. 3, no. 6, Article ID 062301, 2010.

[16] A. Islam, S. P. Singh, M. Yanagida, M. R. Karim, and L. Han, "Amphiphilic ruthenium(II) terpyridine sensitizers with long alkyl chain substituted $\beta$-diketonato ligands: an efficient coadsorbent free dye-sensitized solar cells," International Journal of Photoenergy, vol. 2011, Article ID 757421, 7 pages, 2011.

[17] A. Mishra, M. K. R. Fischer, and P. Büerle, "Metal-free organic dyes for dye-sensitized solar cells: from structure: property relationships to design rules," Angewandte Chemie: International Edition, vol. 48, no. 14, pp. 2474-2499, 2009.

[18] K.-L. Wu, H.-C. Hsu, K. Chen et al., "Development of thiocyanate-free, charge-neutral $\mathrm{Ru}(\mathrm{II})$ sensitizers for dyesensitized solar cells," Chemical Communications, vol. 48, pp. 5124-5126, 2010.

[19] T. Bessho, E. Yoneda, J. H. Yum et al., "New paradigm in molecular engineering of sensitizers for solar cell applications," Journal of the American Chemical Society, vol. 131, no. 16, pp. 5930-5934, 2009.

[20] S. H. Wadman, J. M. Kroon, K. Bakker et al., "Cyclometalated ruthenium complexes for sensitizing nanocrystalline $\mathrm{TiO}_{2}$ solar cells," Chemical Communications, no. 19, pp. 1907-1909, 2007.

[21] S. H. Wadman, M. Lutz, D. M. Tooke et al., "Consequences of $N, C, N^{\prime}$ - and $C, N, N^{\prime}$-coordination modes on electronic and photophysical properties of cyclometalated aryl ruthenium(II) complexes," Inorganic Chemistry, vol. 48, no. 5, pp. 1887-1900, 2009.

[22] P. G. Bomben, K. C. D. Robson, P. A. Sedach, and C. P. Berlinguette, "On the viability of cyclometalated $\mathrm{Ru}(\mathrm{II})$ complexes for light-harvesting applications," Inorganic Chemistry, vol. 48, no. 20, pp. 9631-9643, 2009. 
[23] B. D. Koivisto, K. C. D. Robson, and C. P. Berlinguette, "Systematic manipulation of the light-harvesting properties for tridentate cyclometalated ruthenium(II) complexes," Inorganic Chemistry, vol. 48, no. 20, pp. 9644-9652, 2009.

[24] S. H. Wadman, J. M. Kroon, K. Bakker, R. W. A. Havenith, G. P. M. Van Klink, and G. Van Koten, "Cyclometalated organoruthenium complexes for application in dye-sensitized solar cells," Organometallics, vol. 29, no. 7, pp. 1569-1579, 2010.

[25] M. K. Nazeeruddin, P. Péchy, T. Renouard et al., "Engineering of efficient panchromatic sensitizers for nanocrystalline $\mathrm{TiO}_{2}$ based solar cells," Journal of the American Chemical Society, vol. 123, no. 8, pp. 1613-1624, 2001.

[26] Z. S. Wang, T. Yamaguchi, H. Sugihara, and H. Arakawa, "Significant efficiency improvement of the black dye-sensitized solar cell through protonation of $\mathrm{TiO}_{2}$ films," Langmuir, vol. 21, no. 10, pp. 4272-4276, 2005.

[27] M. Ikeda, N. Koide, L. Han, A. Sasahara, and H. Onishi, "Scanning tunneling microscopy study of black dye and deoxycholic acid adsorbed on a rutile $\mathrm{TiO}_{2}(110)$," Langmuir, vol. 24, no. 15, pp. 8056-8060, 2008.

[28] Z. S. Wang, Y. Cui, Y. Dan-oh, C. Kasada, A. Shinpo, and K. Hara, "Thiophene-functionalized coumarin dye for efficient dye-sensitized solar cells: electron lifetime improved by coadsorption of deoxycholic acid," Journal of Physical Chemistry C, vol. 111, no. 19, pp. 7224-7230, 2007.

[29] P. G. Bomben, B. D. Koivisto, and C. P. Berlinguette, "Cyclometalated Ru complexes of type $\left[\mathrm{Ru}^{\mathrm{II}}\left(N^{\wedge} N\right)_{2}\left(C^{\wedge} N\right)\right]^{\mathrm{z}}$ : physicochemical response to substituents installed on the anionic ligand," Inorganic Chemistry, vol. 49, no. 11, pp. 49604971, 2010.

[30] S. Y. Huang, G. Schlichthörl, A. J. Nozik, M. Grätzel, and A. J. Frank, "Charge recombination in dye-sensitized nanocrystalline $\mathrm{TiO}_{2}$ solar cells," Journal of Physical Chemistry $B$, vol. 101, no. 14, pp. 2576-2582, 1997.

[31] G. Boschloo, L. Häggman, and A. Hagfeldt, "Quantification of the effect of 4-tert-butylpyridine addition to $\mathrm{I}^{-} / \mathrm{I}_{3}{ }^{-}$redox electrolytes in dye-sensitized nanostructured $\mathrm{TiO}_{2}$ solar cells," Journal of Physical Chemistry B, vol. 110, no. 26, pp. 1314413150, 2006. 


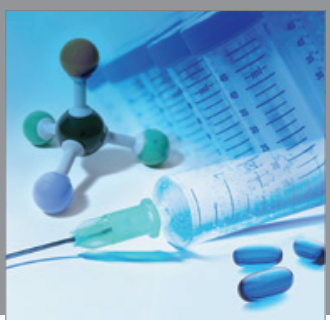

International Journal of

Medicinal Chemistry

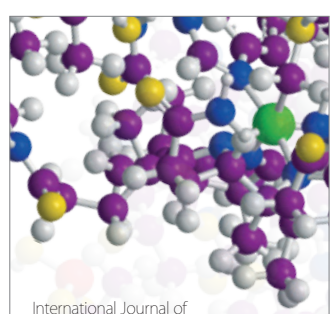

Carbohydrate Chemistry

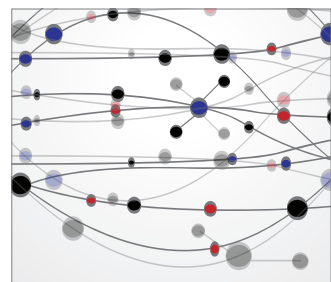

The Scientific World Journal
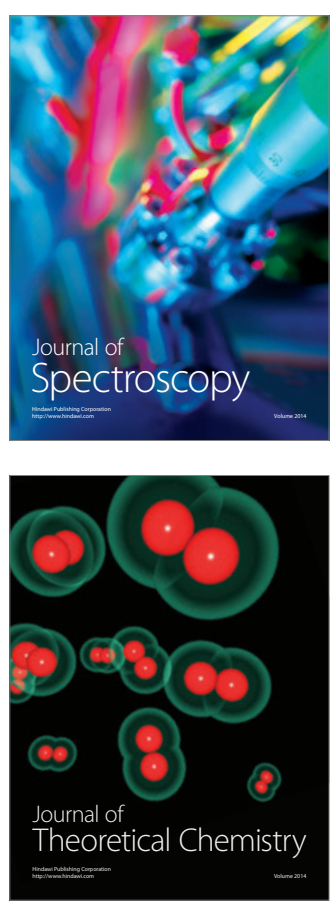
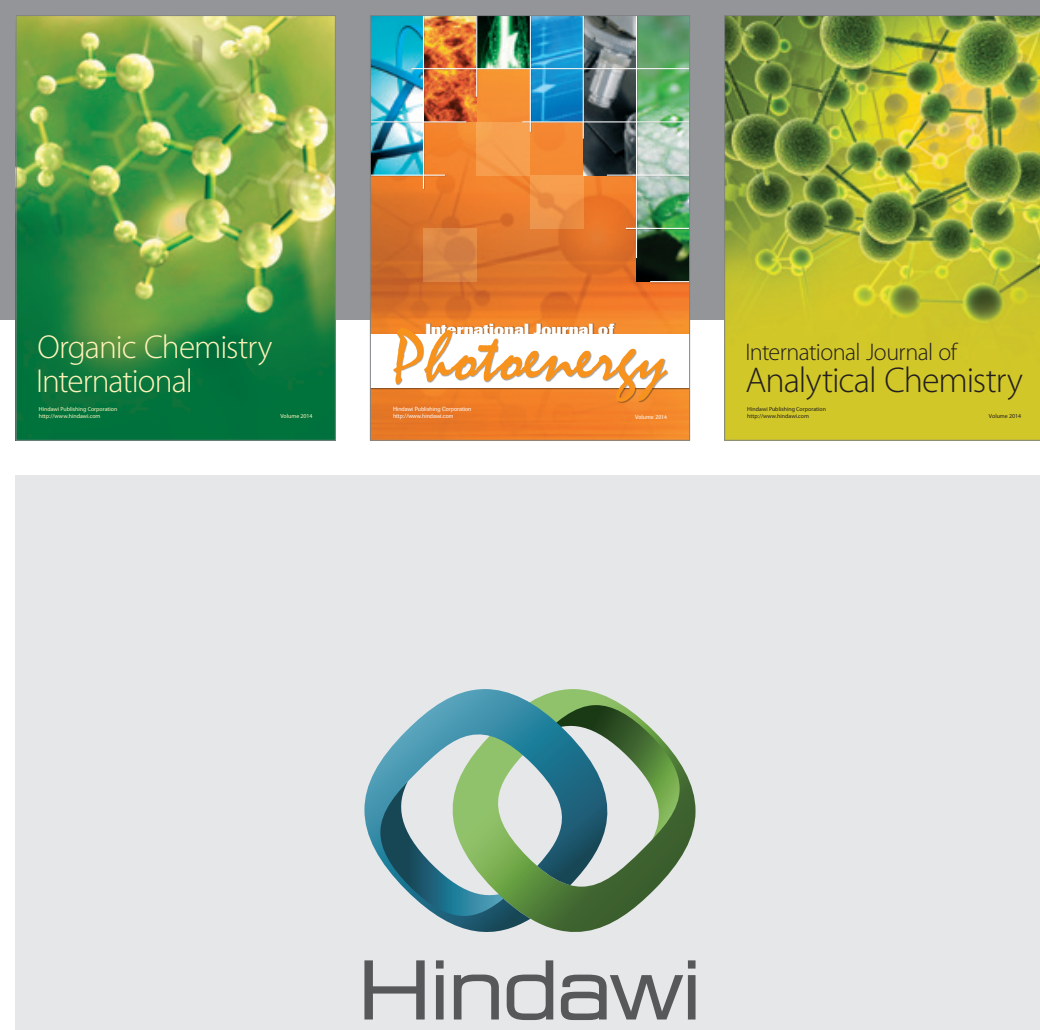

Submit your manuscripts at

http://www.hindawi.com
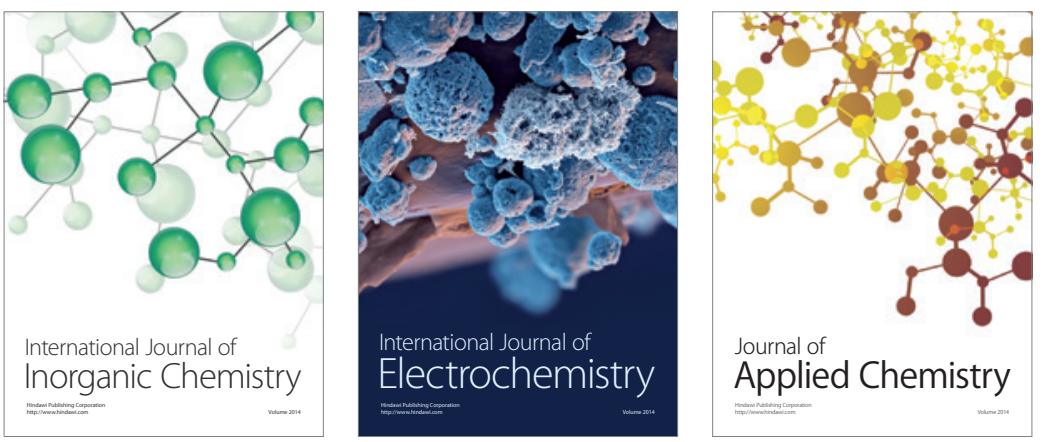

Journal of

Applied Chemistry
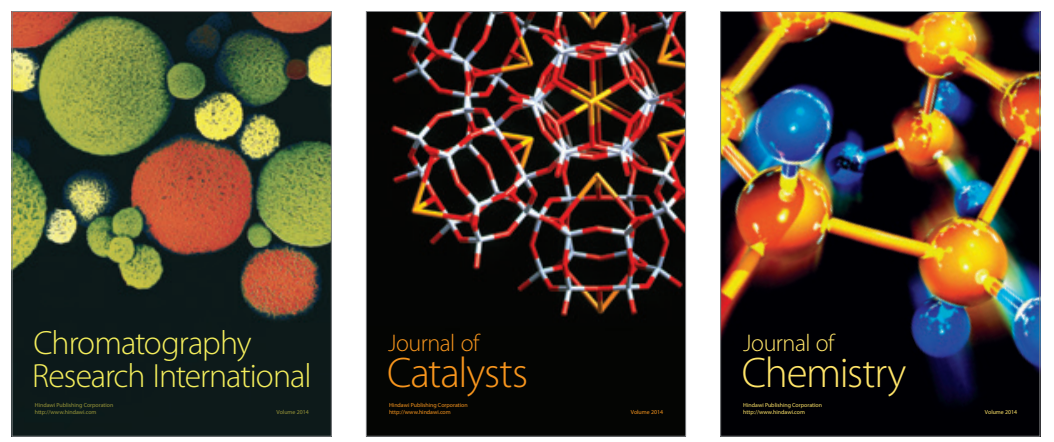
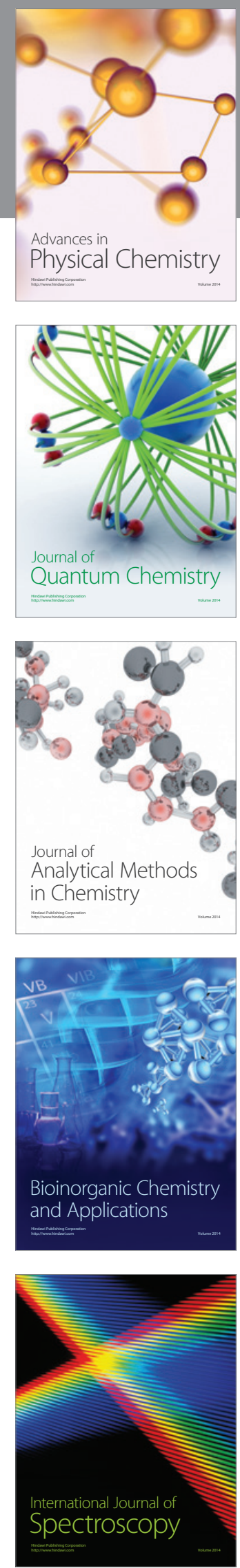